\title{
Accumulation of valuable secondary metabolites: phenolic acids and flavonoids in different in vitro systems of shoot cultures of the endangered plant species-Eryngium alpinum $\mathrm{L}$.
}

\author{
Małgorzata Kikowska $^{1}$ (D) $\cdot$ Barbara Thiem ${ }^{1} \cdot$ Agnieszka Szopa $^{2} \cdot$ Halina Ekiert $^{2}$
}

Received: 7 November 2019 / Accepted: 11 February 2020 / Published online: 17 February 2020

(c) The Author(s) 2020

\begin{abstract}
In vitro cultures give the opportunity to perform the phytochemical studies on the protected species without harvesting the plant material from the natural environment. Shoots of Eryngium alpinum L. were multiplied on Murashige and Skoog (MS) medium in various systems, namely on the solid media and in two liquid cultures—stationary and agitated, as well as via regeneration from callus. The biomass increments were closely correlated with the number of shoots arising from one explant, which was connected with the supplementation of the culture media with the studied plant growth regulators. The methanolic extracts from shoots grown in the tested systems were subjected to phenolic acids and flavonoids qualitative and quantitative analysis. Biomass from in vitro shoot cultures accumulated from 19.59 to 32.95 times more phenolic acids [the total content ranged from 272.52 to $458.38 \mathrm{mg} / 100 \mathrm{~g}$ dry weight (DW)] and from 3.02 to 4.43 times more flavonoids (the total content ranged from 100.03 to $146.98 \mathrm{mg} / 100 \mathrm{~g} \mathrm{DW}$ ), depending on the culture system, than the extracts from basal leaves from the intact plant (13.91 and $33.16 \mathrm{mg} / 100 \mathrm{~g} \mathrm{DW}$, respectively). The phenolics present in shoot cultures include seven phenolic acids-3,4-dihydroxyphenylacetic, caftaric, caffeic, neochlorogenic, chlorogenic, isochlorogenic, and rosmarinic acids, and three flavonoids-isoquercetin, quercitrin and robinin. The best system for shoot proliferation resulting in the highest biomass growth and phenolic acids and flavonoids accumulation was solid culture on MS medium with BAP, IAA, and $\mathrm{GA}_{3}$ (each $1.0 \mathrm{mg} / \mathrm{l}$ ). The aim of this work was to check the effect of various culture systems (stationary and agitated, on solidified and in liquid media) on the production of phenolic compounds in E. alpinum shoots cultured in vitro.
\end{abstract}

\section{Key message}

This is the first report on phenolic acids and flavonoids estimation in Eryngium alpinum in vitro biomass from different culture systems.

Keywords Alpine eryngo $\cdot$ Shoot multiplication $\cdot$ Phenolic acids $\cdot$ Flavonoids $\cdot$ HPLC-DAD analysis

\section{Introduction}

Communicated by Mohammad Faisal.

Małgorzata Kikowska

kikowska@ump.edu.pl

1 Department of Pharmaceutical Botany and Plant Biotechnology, University of Medical Sciences in Poznan, 14 Św. Marii Magdaleny St., 61-861 Poznań, Poland

2 Department of Pharmaceutical Botany, Jagiellonian University, Collegium Medicum, 9 Medyczna St., 30-688 Kraków, Poland
Eryngium alpinum L. (Alpine eryngo) from the subfamily Saniculoideae of the Apiaceae is listed in Annex II of the Habitats Directive and Appendix I of the Convention on the Conservation of European Wildlife and Natural Habitats (The Bern Convention) and it is protected by the European Habitats Directive-Natura 2000 as well as the national red lists of some European countries (Gygax et al. 2013). The species is considered vulnerable by the International Union for the Conservation of Nature (IUCN) (Gillot and Garraud 1995). Some of the individuals are threatened by humansthe plant is collected for ornamental and commercial use and 
affected by changes in habitats and climate. For these reasons, some populations have decreased in size, while others have disappeared (Gaudeul and Till-Bottraud 2004).

Due to the protection status of this taxon, it is not possible to harvest the raw material from the natural sites; therefore, in vitro cultures can become its alternative source. In vitro cultures bring several advantages-they enable continuous production of uniform biomass from rare and protected plants independently of climatic and environmental conditions. Moreover, plant biomass with good biotechnological parameters (for example growth rate, biomass doubling time, cell weight yield) may become the material for the phytochemical and biological research without the need to deplete natural environments (Espinosa-Leal et al. 2018).

To the best of the authors' knowledge, E. alpinum has not been used in traditional medicine. However, according to the literature, cultures worldwide have used Eryngium species as medicines, e.g. E. campestre as antitussive, diuretic, appetizer, stimulant, and aphrodisiac, E. creticum for scorpion stings as well as a hypoglycemic agent, $E$. elegans for diuretic purposes, E. foetidum for the treatment of several anti-inflammatory disorders, E. alismifolium, $E$. aquaticum, E. yuccifolium for diarrhea, E. aquaticum for poisons, tapeworms, and venereal diseases, E. yuccifolium for snakebites, toothache, headache, and kidney troubles, as well as for some digestive system problems (Wang et al. 2012; Kikowska and Thiem 2020).

Due to the inaccessibility of the material for the phytochemical research, these plants have been examined to a small extent. The presence of several phenolic acids-chlorogenic acid, rosmarinic acid, and its derivative- $\mathrm{R}-(+)-3^{\prime} \mathrm{O}-$ $\beta$-D-glucopyranosyl rosmarinic acid (Le Claire et al. 2005) and flavonoids - quercetin and kaempferol (Crowden et al. 1969), and the essential oil (Dunkic et al. 2013) was detected in the organs of ground plant. The main phenolic compounds estimated in the methanolic extract of shoots were-3,4-dihydroxyphenylacetic acid, chlorogenic and isochlorogenic acids, rosmarinic acid, as well as isoquercetin (Kikowska et al. 2019). Moreover, the major constituents identified by GC-FID and GC/MS in the essential oil of E. alpinum isolated by hydrodistillation of the aerial parts of the plant were caryophyllene oxide (21.6\%) and $\alpha$-bisabolol from oxygenated sesquiterpenes (7.8\%) as well as bicyclogermecrene (11.8\%) and germacrene D (10.3\%) (Dunkic et al. 2013). The crude extract of roots rich in phenolic acids determined by HPLC-DAD demonstrated the antioxidant activity (Le Claire et al. 2005) and the essential oil of the aerial parts showed the antiphytoviral effect (Dunkic et al. 2013).

Phenolic compounds are a large group of plant bioactive compounds showing a diversity of structures (Cheynier 2012). The variety of health-promoting benefits of this class of secondary metabolites include, for example, antioxidant, antibacterial, antifungal, antiviral, anti-inflammatory, and antimutagenic activities. Phenolics have also been studied for the inhibition of the initiation and progression of cancer, preventing or delaying the onset of hypertension, and as therapeutic molecules in Alzheimer's disease, etc. (Garg et al. 2019). The production of phenolic compounds under in vitro culture conditions has been wider discussed in some current reviews (Matkowski 2008; Smetanska 2018).

The aim of the study was to obtain shoot biomass of $E$. alpinum under in vitro conditions and to perform the comprehensive quantification of phenolic acids and flavonoids. Shoots were multiplied employing the axillary bud proliferation technique on the solid media and in two different liquid media systems - stationary and agitated, as well as in shoots regenerated from callus via indirect organogenesis. All the variants of Murashige and Skoog (MS) media were augmented with 6-benzylaminopurine (BAP), indole-3-acetic acid (IAA), gibberellic acid $\left(\mathrm{GA}_{3}\right)$ in different combinations, namely BAP, BAP and IAA, and BAP, IAA, and $\mathrm{GA}_{3}$, at the same concentration $(1.0 \mathrm{mg} / \mathrm{l})$. The present work examined the influence of the culture systems and plant growth regulators on multiplication rate and biomass growth as well as the effect of the selected in vitro systems on the accumulation of the studied phenolic compounds in shoots.

\section{Materials and methods}

\section{Plant material}

The primary explants, namely fruits, roots, basal and stem leaves as well as small plantlets of Eryngium alpinum L. were collected from Adam Mickiewicz Botanical Garden in Poznań, Poland in September 2017. The voucher specimen has been deposited in the Department of Pharmaceutical Botany and Plant Biotechnology of Poznań University of Medical Sciences under the number H-AP-2017-102. The organs (fruits, roots, and leaves) from the intact plant were used for the comparative phytochemical analyses, while small individuals (fragments with lateral buds) were used as explants to establish and stabilize shoot cultures under controlled conditions.

\section{Shoot cultures initiation}

The explants were surface disinfected according to the procedure adopted by Kikowska et al. (2019). Briefly, the fragments with lateral buds were pre-treated with an ethanol-water solution $(70 \%)$ and then treated with a sodium hypochlorite solution $(2.5 \%)$ with a few drops of surfactantTween $80 \%$. After the final wash with the autoclaved double-distilled water, the explants were placed in Erlenmeyer flask with $50 \mathrm{ml}$ solidified MS medium (Murashige and Skoog 1962) with PGRs-benzylaminopurine (BAP; 
Sigma-Aldrich, Saint Louis, USA), indole-3-acetic acid (IAA; Sigma-Aldrich, Saint Louis, USA), gibberellic acid $\left(\mathrm{GA}_{3}\right.$; Sigma-Aldrich, Saint Louis, USA) each at a concentration of $1.0 \mathrm{mg} / \mathrm{l}$ (Kikowska et al. 2019).

The aseptic explants were the source for experimentsshoot multiplication on the agar media (solid cultures), shoot multiplication in the liquid media (liquid cultures-stationary and agitated) as well as shoot regeneration from organogenic callus. The media were autoclaved at $121{ }^{\circ} \mathrm{C}$, at a pressure of 0.1 MPa for $20 \mathrm{~min}$. Different shoot multiplication systems were compared examining the impact of plant growth regulators on biomass growth. The cultures were grown under artificial light $-55 \mu \mathrm{mol} / \mathrm{m}^{2} \mathrm{~s}(16 \mathrm{~h} \mathrm{light} / 8 \mathrm{~h}$ dark photoperiod) and at a temperature of $21{ }^{\circ} \mathrm{C} \pm 2{ }^{\circ} \mathrm{C}$ and were subcultured at 40 days intervals.

\section{Shoot cultures on agar media (solid cultures)}

Shoots were multiplied via the axillary branching method on MS medium solidified with $7.6 \mathrm{~g} / \mathrm{l}$ agar and enriched with BAP $1.0 \mathrm{mg} / \mathrm{l}$; BAP $1.0 \mathrm{mg} / \mathrm{l}$ and IAA $1.0 \mathrm{mg} / \mathrm{l}$; BAP $1.0 \mathrm{mg} / \mathrm{l}$, IAA $1.0 \mathrm{mg} / \mathrm{l}$ and $\mathrm{GA}_{3} 1.0 \mathrm{mg} / \mathrm{l}$ for a few passages. The $250 \mathrm{ml}$ Erlenmeyer flasks with $50 \mathrm{ml}$ of the medium were used. After 40 days of culture, the percentage of explant-regenerated shoots, the number of new shoots per explant, their length and fresh biomass were measured. Experiments were repeated three times for 30 explants (three explants per flask).

\section{Shoot cultures in liquid media (agitated cultures)}

Shoots were multiplied via the axillary branching method in liquid MS medium enriched with BAP $1.0 \mathrm{mg} / \mathrm{l}$; BAP $1.0 \mathrm{mg} / \mathrm{l}$ and IAA $1.0 \mathrm{mg} / \mathrm{l}$; BAP $1.0 \mathrm{mg} / \mathrm{l}$, IAA $1.0 \mathrm{mg} / \mathrm{l}$ and $\mathrm{GA}_{3} 1.0 \mathrm{mg} / \mathrm{l}$. The $250 \mathrm{ml}$ Erlenmeyer flasks with $30 \mathrm{ml}$ of medium were used. The cultures were maintained on a rotary shaker $(110 \mathrm{rpm})$. After 40 days of culture, the percentage of explant-regenerated shoots, the number of new shoots per explant, their length, and dried biomass were measured. Experiments were repeated three times for ten explants (one explant per flask).

\section{Shoot cultures in liquid media (stationary cultures, without agitation)}

Shoots were multiplied via the axillary branching method in liquid MS medium enriched with BAP $1.0 \mathrm{mg} / \mathrm{l}$; BAP $1.0 \mathrm{mg} / \mathrm{l}$ and IAA $1.0 \mathrm{mg} / \mathrm{l}$; BAP $1.0 \mathrm{mg} / \mathrm{l}$, IAA $1.0 \mathrm{mg} / \mathrm{l}$ and $\mathrm{GA}_{3} 1.0 \mathrm{mg} / \mathrm{l}$. The $250 \mathrm{ml}$ Erlenmeyer flasks with $30 \mathrm{ml}$ of medium were used. In order to avoid complete explant submersion in the liquid medium, the stationary liquid culture was supported by paper bridges placed at the bottom of a culture vessel. The supporting material was placed at the bottom of the culture vessel so that the shoots grown in the liquid media had only partial contact with the nutrients. After 40 days of culture, the percentage of explant-regenerated shoots, the number of new shoots per explant, their length, and dried biomass were measured. Experiments were repeated three times for 10 explants (one explant per flask).

\section{Shoot cultures regenerated from callus}

The leaf blade and petiole were the explants for the callus induction on MS medium supplemented with dicamba (Dic $1.0 \mathrm{mg} / \mathrm{l}$ ) and thidiazuron (TDZ $0.5 \mathrm{mg} / \mathrm{l})$. Callus ( $1.0 \mathrm{~g}$ ) was transferred to MS medium with BAP $1.0 \mathrm{mg} / \mathrm{l}$; BAP $1.0 \mathrm{mg} / \mathrm{l}$ and IAA $1.0 \mathrm{mg} / \mathrm{l} ;$ BAP $1.0 \mathrm{mg} / \mathrm{l}$, IAA $1.0 \mathrm{mg} / \mathrm{l}$ and $\mathrm{GA}_{3} 1.0 \mathrm{mg} / \mathrm{l}$. After 40 days of culture, the percentage of explant-regenerated shoots, the number of new shoots per explant, their length, and dried biomass were measured. Experiments were repeated three times for ten explants (one explant per flask).

\section{HPLC-DAD analysis}

In order to conduct the analysis, the exact amounts of fresh biomass from fruits, roots, stem and basal leaves from the intact plants of E. alpinum, as well as shoots from the tested in vitro culture systems were dried at $40{ }^{\circ} \mathrm{C}$ for $24 \mathrm{~h}$ to a constant weight. The samples of the dried and pulverized plant material, $0.5 \mathrm{~g}$ dry weight (DW) each, were extracted by sonication (Polsonic ${ }^{\circledR} 3$, Poland) in methanol $(5 \mathrm{ml})$ for $30 \mathrm{~min}$ two times. The validated HPLC-DAD method was employed for the analyses of phenolic acids and flavonoids in the extracts (according to Ellnain-Wojtaszek and Zgorka 1999). All the specifics of HPLC-DAD analysis, equipment, and conditions were outlined by us previously (Szopa et al. $2017 \mathrm{a}, \mathrm{b})$. The identification of compounds was carried out on the basis of UV spectra $(\lambda=200-400 \mathrm{~nm}), t_{R}$ values, and the internal standard method, with the application of the reference substances. To perform the quantification, peak measurements and the standard curves were compared. To the analyses were applied the standards of phenolic acids from Sigma-Aldrich (Saint Louis, USA) that included: 3,4-dihydroxyphenylacetic acid, caftaric acid, caffeic acid, chlorogenic acid, $o$-coumaric, $m$-coumaric, $p$-coumaric acids, ferulic acid, gallic acid, gentisic acid, hydrocaffeic acid, $p$-hydroxybenzoic acid, isochlorogenic acid, isoferulic acid, neochlorogenic acid, protocatechuic acid, rosmarinic acid, salicylic acid, sinapic acid, syringic acid and vanillic acid, and benzoic and cinnamic acids (precursors of phenolic acids) (23 compounds). Moreover, the flavonoid standards including aglycones (isorhamnetin kaempferol, luteolin, quercetin, rhamnetin, and myricetin) and glycosides (apigetrin, cynaroside, hyperoside, populnin, quercitrin, 
rutoside, trifolin, and vitexin) were used (14 compounds) (Sigma-Aldrich, Saint Louis, USA).

\section{Statistical analysis}

The obtained data were analyzed using a one-way analysis of variance (ANOVA) and the statistical significance was determined by Duncan's post-hoc test (P-value of 0.05). All the analyses were conducted using STATISTICA v. 13 (StatSoft Inc.).

\section{Results and discussion}

Eryngium alpinum was introduced into in vitro cultures and the capacity to produce the desired phenolics-phenolic acids and flavonoids by shoots cultured on the media supplemented with different phytohormones was measured (Kikowska et al. 2019). In the previous work, the effect of various combinations of plant growth regulators on the accumulation of phenolic compounds in shoots and callus maintained on solid media was examined. Previously, the shoots were multiplied on agar-gelled media, but no studies have been conducted for estimation of the potential of shoot multiplication in liquid systems (stationary and agitated). In this work, the effect of various breeding systems (stationary and agitated, on solidified and in liquid media) on the production of phenolics in shoots kept on/in media supplemented with previously selected phytohormones was studied.

Although there are approximately 230-250 species of Eryngium in the world, only few have been introduced into in vitro cultures, namely E. foetidum (Arockisamy and Ignacimuthu 1998; Ignacimuthu et al. 1999; Arockisamy et al. 2002; Martin 2004; Chandrika et al. 2011), E. planum (Kikowska et al. 2012, 2015; Thiem et al. 2013), E. maritimum (Kikowska et al. 2014), E. campestre (Kikowska et al. 2016), and E. viviparum (Ayuso et al. 2019).

The limitation of seed production by E. alpinum, endogenous morphological dormancy of seeds, and the low germination rate make the generative propagation of this species very inefficient (Njenga 1995; Gaudeul and Till-Bottraud 2004). For this reason, the small fragments of plantlets, after disinfection, were the source of the explants for the biotechnological experiments.

Shoots of E. alpinum multiplied on the solid media and in the liquid media without agitation were characterized by intense green color and correct morphology, while agitated shoots from the liquid media were characterized by their abnormality and hyperhydricity (Fig. 1). Several authors have also reported this observation, for example, for Scutellaria alpina (Grzegorczyk-Karolak et al. 2017). The shoot multiplication rate of E. alpinum was culture systemand phytohormone-dependent (Table 1). The proliferation parameters were better for shoots grown on the solid media
Fig. 1 Eryngium alpinum L. a Intact plant from Adam Mickiewicz Botanical Garden in Poznań (Poland), b shoot culture in a stationary liquid medium, c shoot cultures in the liquid media on the rotary shaker, $\mathbf{d}$ shoot culture on an agar medium, e shoots regenerated from callus, $\mathbf{f}$ shoot cultures on the agar media in the growth chamber. All MS media supplemented with BAP $(1.0 \mathrm{mg} / \mathrm{l})$, IAA $(1.0 \mathrm{mg} / \mathrm{l})$ and $\mathrm{GA}_{3}(1.0 \mathrm{mg} / \mathrm{l})$

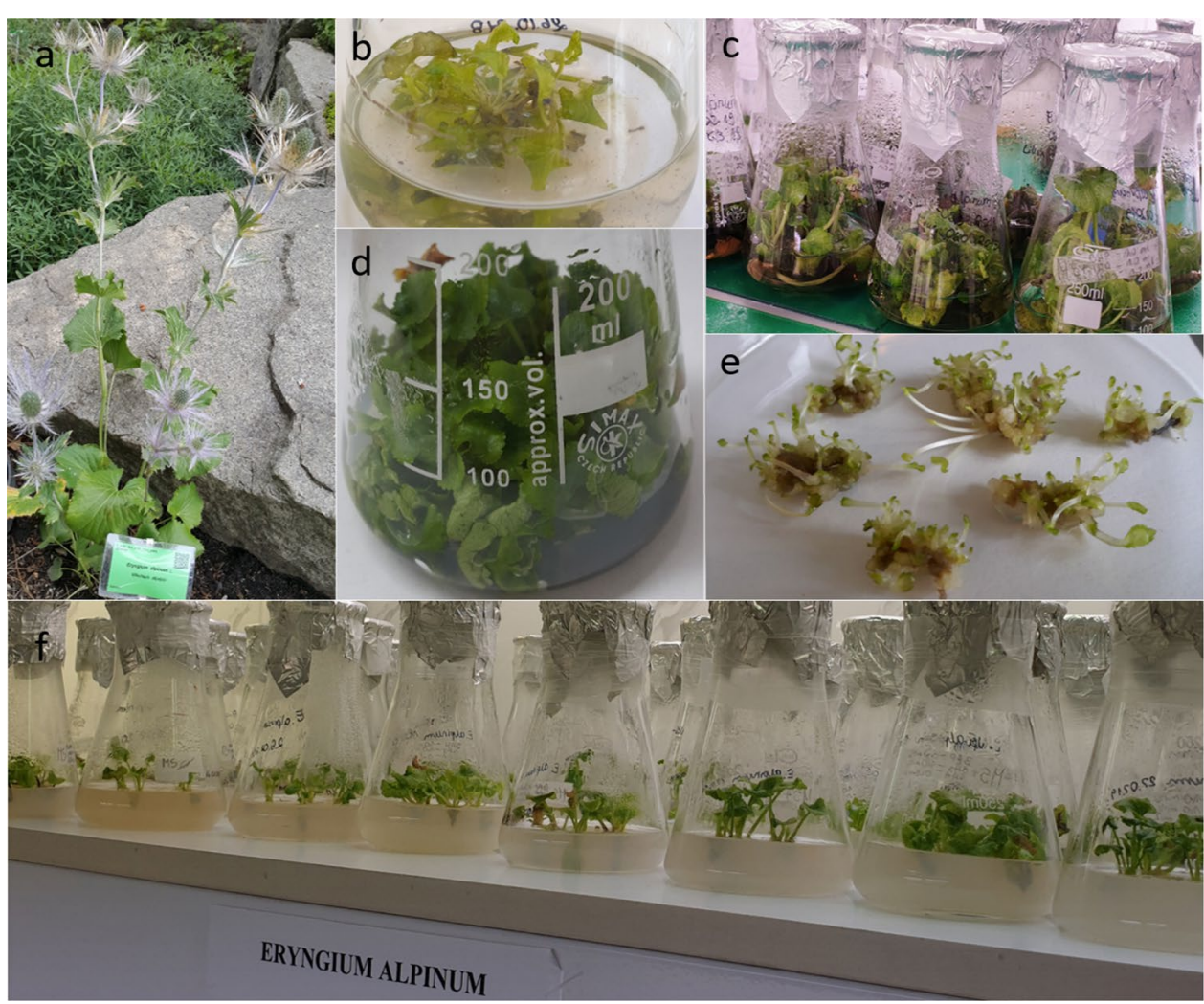


Table 1 The effect of tested plant growth regulators (1.0 mg/l each) and culture system on Eryngium alpinum biomass parameters

\begin{tabular}{|c|c|c|c|c|c|c|}
\hline \multicolumn{3}{|c|}{ MS medium supplementation } & \multicolumn{4}{|c|}{ Biomass parameters } \\
\hline Cytokinin & Auxin & Gibberelin & Induction $(\%)$ & $\begin{array}{l}\text { Shoot number/ } \\
\text { explant } \pm \mathrm{SD}\end{array}$ & Shoot length $[\mathrm{CM}] \pm \mathrm{SD}$ & $\begin{array}{l}\text { Dried biomass/ } \\
\text { shoot }[\mathrm{G}] \pm \mathrm{SD}\end{array}$ \\
\hline \multicolumn{7}{|c|}{ Shoot cultures on solid media } \\
\hline- & - & - & 50 & $2.83 \pm 0.74^{\mathrm{fg}}$ & $3.60 \pm 0.86^{\mathrm{c}}$ & $0.06 \pm 0.01^{\mathrm{d}}$ \\
\hline BAP & - & - & 100 & $7.80 \pm 2.28^{\mathrm{cd}}$ & $2.24 \pm 0.60^{\mathrm{efg}}$ & $0.18 \pm 0.02^{\mathrm{c}}$ \\
\hline BAP & IAA & - & 100 & $10.63 \pm 2.44^{\mathrm{b}}$ & $2.43 \pm 0.38^{\mathrm{e}}$ & $0.39 \pm 0.02^{\mathrm{ab}}$ \\
\hline BAP & IAA & $\mathrm{GA}_{3}$ & 100 & $13.70 \pm 2.15^{\mathrm{a}}$ & $2.05 \pm 1.01^{\mathrm{gh}}$ & $0.44 \pm 0.03^{\mathrm{a}}$ \\
\hline \multicolumn{7}{|c|}{ Shoot cultures in liquid media agitated } \\
\hline- & - & - & 100 & $2.60 \pm 0.93^{\mathrm{fg}}$ & $3.43 \pm 0.80^{\mathrm{d}}$ & $0.05 \pm 0.02^{\mathrm{d}}$ \\
\hline BAP & - & - & 100 & $7.16 \pm 1.68^{\mathrm{de}}$ & $4.64 \pm 1.23^{\mathrm{ab}}$ & $0.18 \pm 0.01^{\mathrm{c}}$ \\
\hline BAP & IAA & - & 100 & $10.13 \pm 2.37^{\mathrm{b}}$ & $4.81 \pm 0.93^{\mathrm{a}}$ & $0.38 \pm 0.03^{\mathrm{b}}$ \\
\hline BAP & IAA & $\mathrm{GA}_{3}$ & 100 & $13.13 \pm 2.71^{\mathrm{a}}$ & $4.52 \pm 0.67^{\mathrm{bc}}$ & $0.41 \pm 0.04^{\mathrm{ab}}$ \\
\hline \multicolumn{7}{|c|}{ Shoot cultures in liquid media stationary } \\
\hline- & - & - & 75 & $3.36 \pm 0.76^{\mathrm{f}}$ & $2.3 \pm 0.55^{\mathrm{ef}}$ & $0.07 \pm 0.02^{\mathrm{d}}$ \\
\hline BAP & - & - & 100 & $6.73 \pm 1.20^{\mathrm{e}}$ & $1.89 \pm 0.53^{\mathrm{h}}$ & $0.17 \pm 0.02^{\mathrm{c}}$ \\
\hline BAP & IAA & - & 100 & $8.43 \pm 1.35^{\mathrm{c}}$ & $1.58 \pm 0.48^{\mathrm{i}}$ & $0.22 \pm 0.03^{c}$ \\
\hline BAP & IAA & $\mathrm{GA}_{3}$ & 100 & $9.93 \pm 1.31^{\mathrm{b}}$ & $1.60 \pm 0.52^{\mathrm{i}}$ & $0.34 \pm 0.04^{\mathrm{b}}$ \\
\hline \multicolumn{7}{|c|}{ Shoots regenerated from callus } \\
\hline- & - & - & 10 & 0 & - & - \\
\hline BAP & - & - & 40 & $1.23 \pm 0.67^{\mathrm{hi}}$ & $2.24 \pm 0.79^{\mathrm{efg}}$ & $0.04 \pm 0.00^{\mathrm{e}}$ \\
\hline BAP & IAA & - & 45 & $1.10 \pm 0.71^{\mathrm{h}}$ & $2.12 \pm 0.48^{\mathrm{fg}}$ & $0.04 \pm 0.00^{\mathrm{e}}$ \\
\hline BAP & IAA & $\mathrm{GA}_{3}$ & 100 & $2.00 \pm 0.83^{\mathrm{gh}}$ & $1.67 \pm 0.47^{\mathrm{i}}$ & $0.05 \pm 0.01^{\mathrm{d}}$ \\
\hline
\end{tabular}

Mean values with a column with the same letter are not significantly different at $\mathrm{P}=0.05$ (Duncan's multiple range test)

and agitated in the liquid media than maintained in the stationary liquid systems or regenerated from callus. Several authors have reported that shoots growth in the liquid media had a lower multiplication rate than those on the agar media, for example, in in vitro cultures of Schisandra chinensis (Szopa et al. 2016), Scutellaria alpina (GrzegorczykKarolak et al. 2017), S. latifolia and S. costaricana (Tascan et al. 2010), and Hypericum perforatum (Savio et al. 2011). Moreover, the effect of the cultivation system on S. chinensis biomass growth was studied and the growth parameters were higher for microshoots maintained as stationary liquid cultures compared with microshoots from the agar-based media and agitated shoots in the agar-free media (Szopa et al. 2016). However, for Scutellaria alpina the multiplication ratio was lower for shoots maintained on the agarbased media in comparison to explants cultured in the liquid media, either agitated or stationary (Grzegorczyk-Karolak et al. 2017). An efficient and rapid method for shoot multiplication of endangered species Arnebia euchroma using agitated liquid cultures was developed by the team of Malik (Malik et al. 2016).

In the present study, the E. alpinum shoot number per explant was higher for shoots multiplied on the phytohormone-supplemented media in comparison to the non-supplemented media. The shoot multiplication ratio increased with the addition of another type of phytohormone to the culture media. The highest parameter was obtained for shoots of E. alpinum grown on the solid MS media with BAP, IAA, and $\mathrm{GA}_{3}(13.70 \pm 2.15)$ and agitated in the liquid MS media with BAP, IAA, and $\mathrm{GA}_{3}(13.13 \pm 1.31)$; it was significantly higher than for shoots from the stationary liquid systems $(9.93 \pm 1.31)$ and also from shoots regenerated from callus $(2.00 \pm 0.83)$ (Table 1$)$. The influence of plant growth regulators on shoot multiplication has been well documented also for other Eryngium species (Thiem et al. 2013; Kikowska et al. 2014, 2016). The influence of BAP and IAA at different concentrations on shoot multiplication on the solid MS media generated from $7.63 \pm 0.60$ to $17.10 \pm 0.60$ shoots per explant for E. planum (Thiem et al. 2013), from $1.2 \pm 0.20$ to $4.4 \pm 0.24$ for E. maritimum (Kikowska et al. 2014), and from $6.70 \pm 1.56$ to $13.30 \pm 3.73$ for $E$. campestre (Kikowska et al. 2016) during 6 weeks of culture (Fig. 2).

The phytochemical studies on the presence and content of phenolic acids showed a large variation between the intact plant materials and the different tested in vitro culture systems (Table 2). Phenolic acids of fruits and stem leaves4-dihydroxybenzoic acid, syringic acid, and vanillic acid, were not detected in basal leaves and roots of the intact plant as well as in any of the biomass from the different tested shoot culture systems. 4-dihydroxybenzoic acid, syringic 


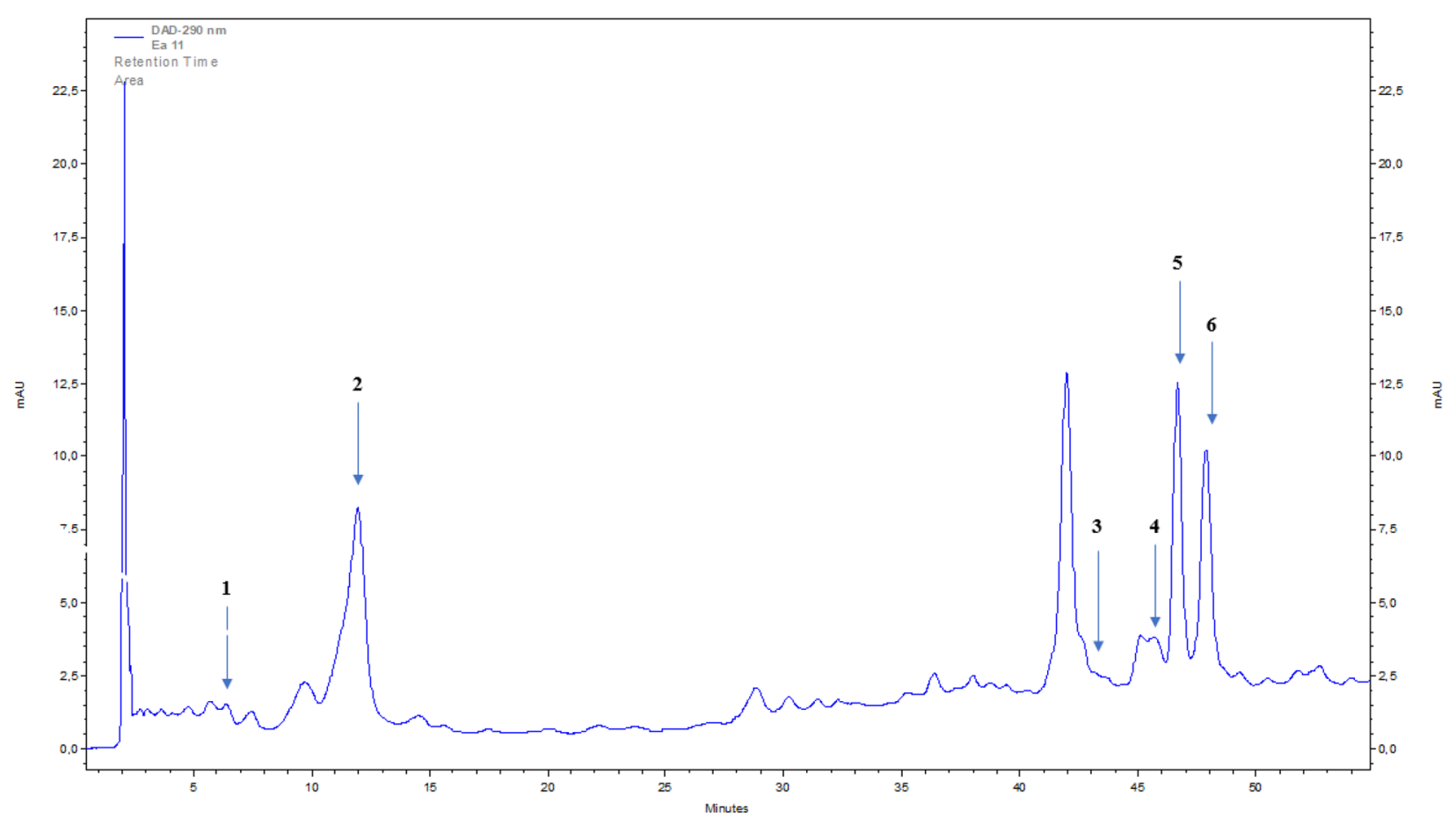

Extract of basal leaves from intact plants: 1 - 3,4-dihydroxyphenylacetic acid, 2 chlorogenic acid, $\mathbf{3}$ - isochlorogenic acid, $\mathbf{4}$ - rosmarinic acid, 5 - trifolin, $\mathbf{6}$ - quercitrin

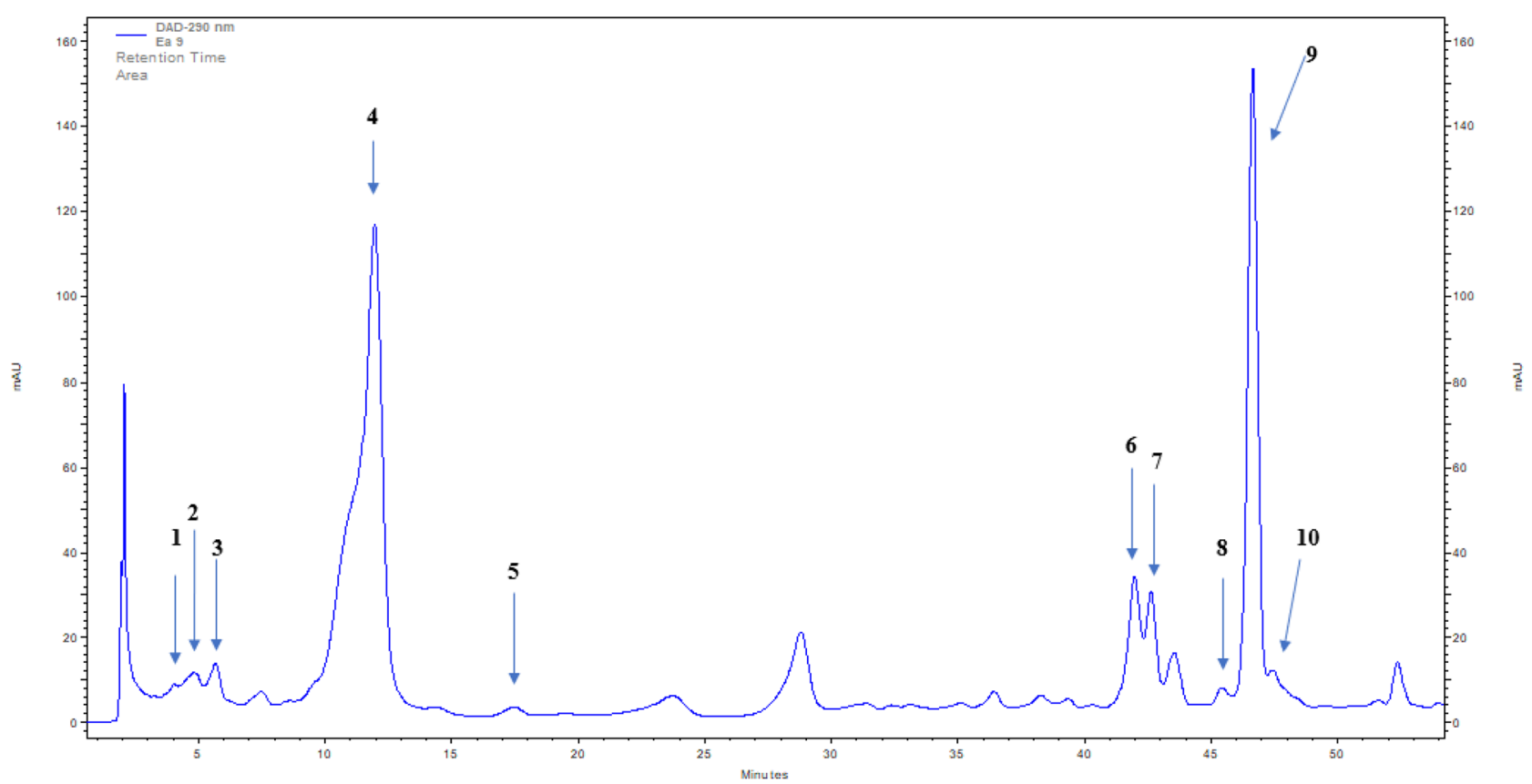

Extract of in vitro shoots from solid media: 1 - caftaric acid, 2 - neochlorogenic acid, 3 3,4-dihydroxyphenylacetic acid, 4 - chlorogenic acid, 5 - caffeic acid, 6 - isochlorogenic acid, 7 - isoquercetin, 8 - robinin, 9 - rosmarinic acid, 10 - quercitrin

Fig. 2 The representative HPLC-UV chromatograms $(\lambda=254 \mathrm{~nm})$ of basal leaves from intact plants and shoot cultures of Eryngium alpinum 


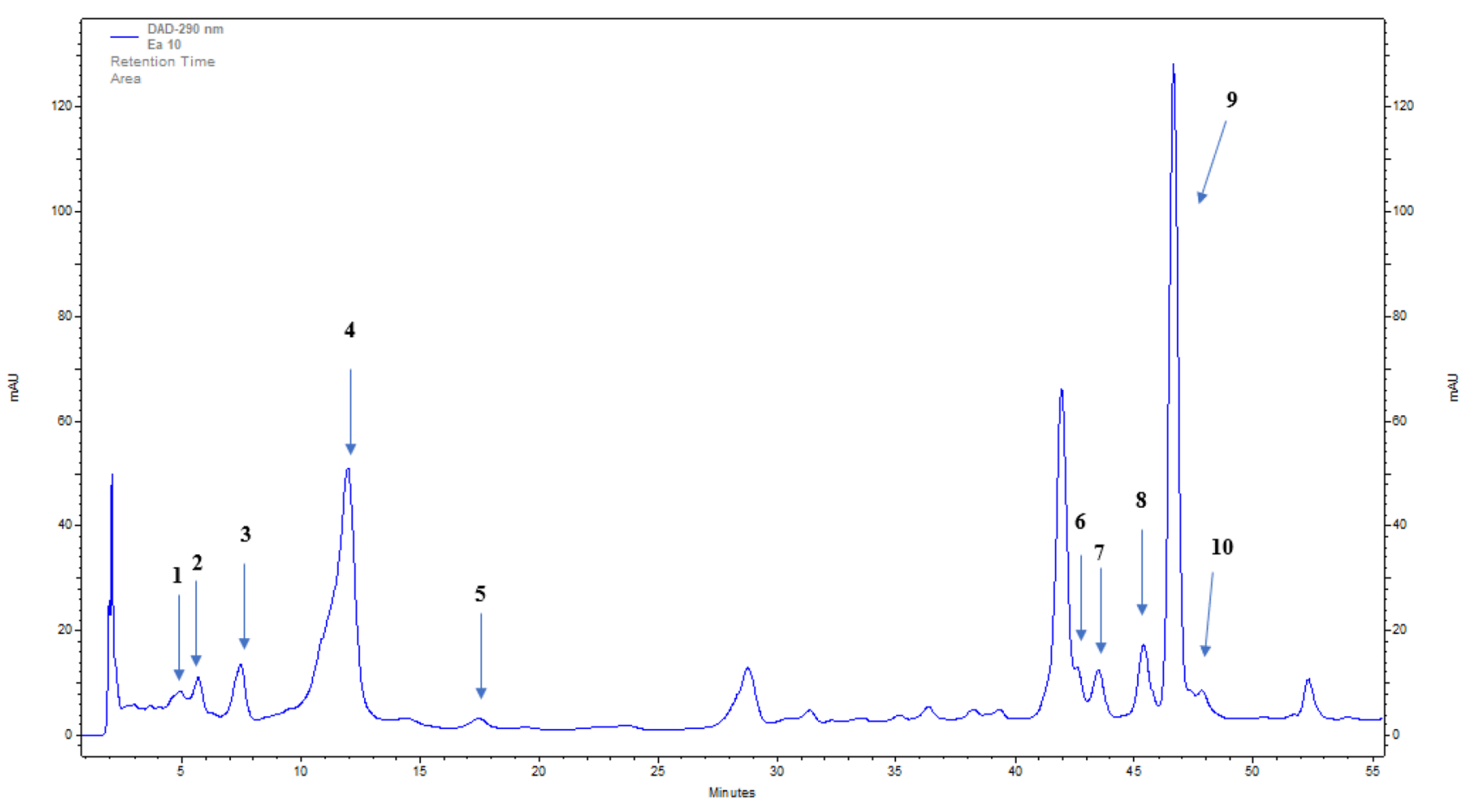

Extract of in vitro shoots from liquid media (agitated): 1 - caftaric acid, $\mathbf{2}$ - neochlorogenic acid, 3 - 3,4-dihydroxyphenylacetic acid, 4 - chlorogenic acid, 5 - caffeic acid, $\mathbf{6}$ isochlorogenic acid, 7 - isoquercetin, 8 - robinin, 9 - rosmarinic acid, 10 - quercitrin

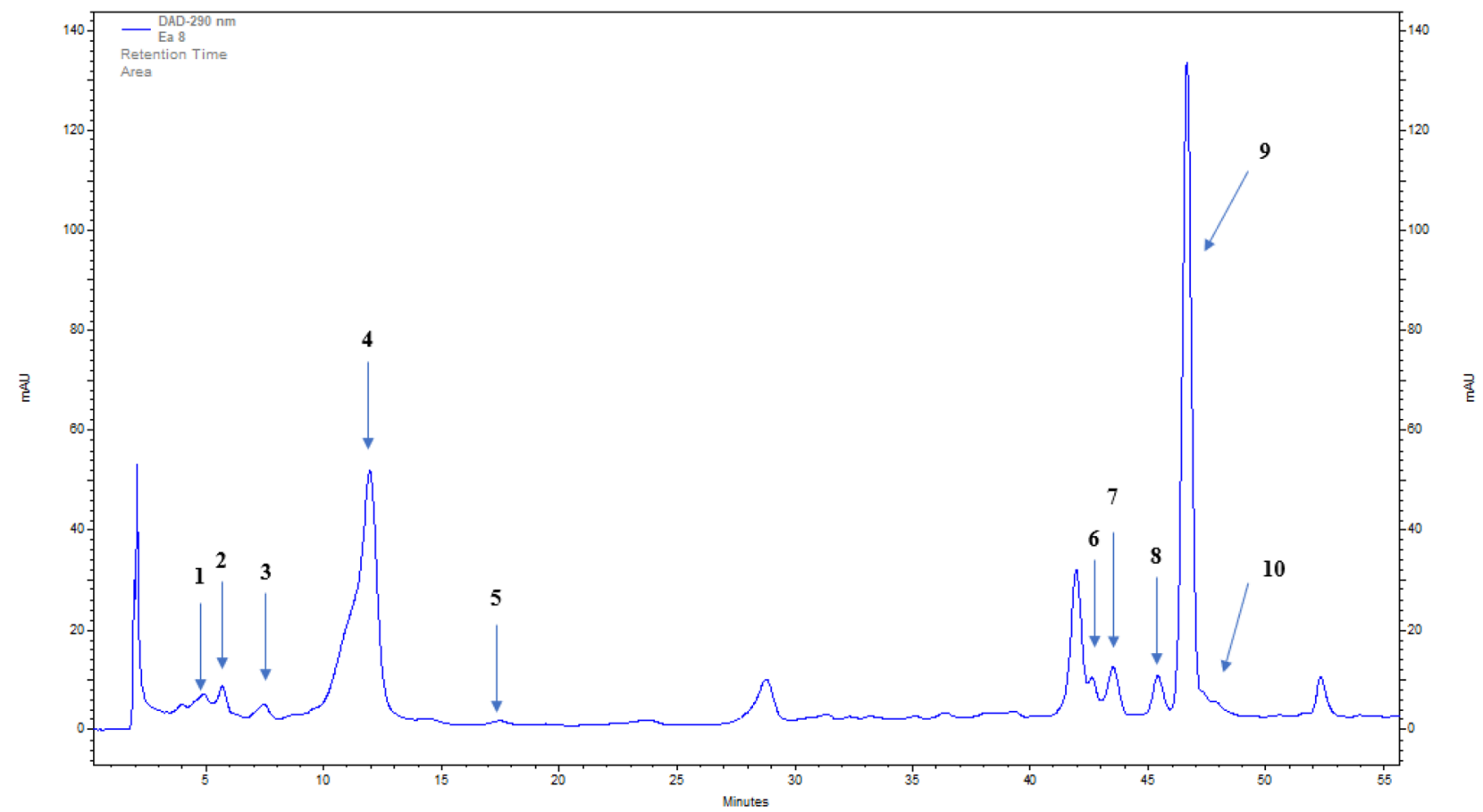

Extract of in vitro shoots from liquid media (stationary): 1 - caftaric acid, $\mathbf{2}$ - neochlorogenic acid, 3 - 3,4-dihydroxyphenylacetic acid, 4 - chlorogenic acid, 5 - caffeic acid, 6 isochlorogenic acid, 7 - isoquercetin, 8 - robinin, 9 - rosmarinic acid, 10 - quercitrin

Fig. 2 (continued) 


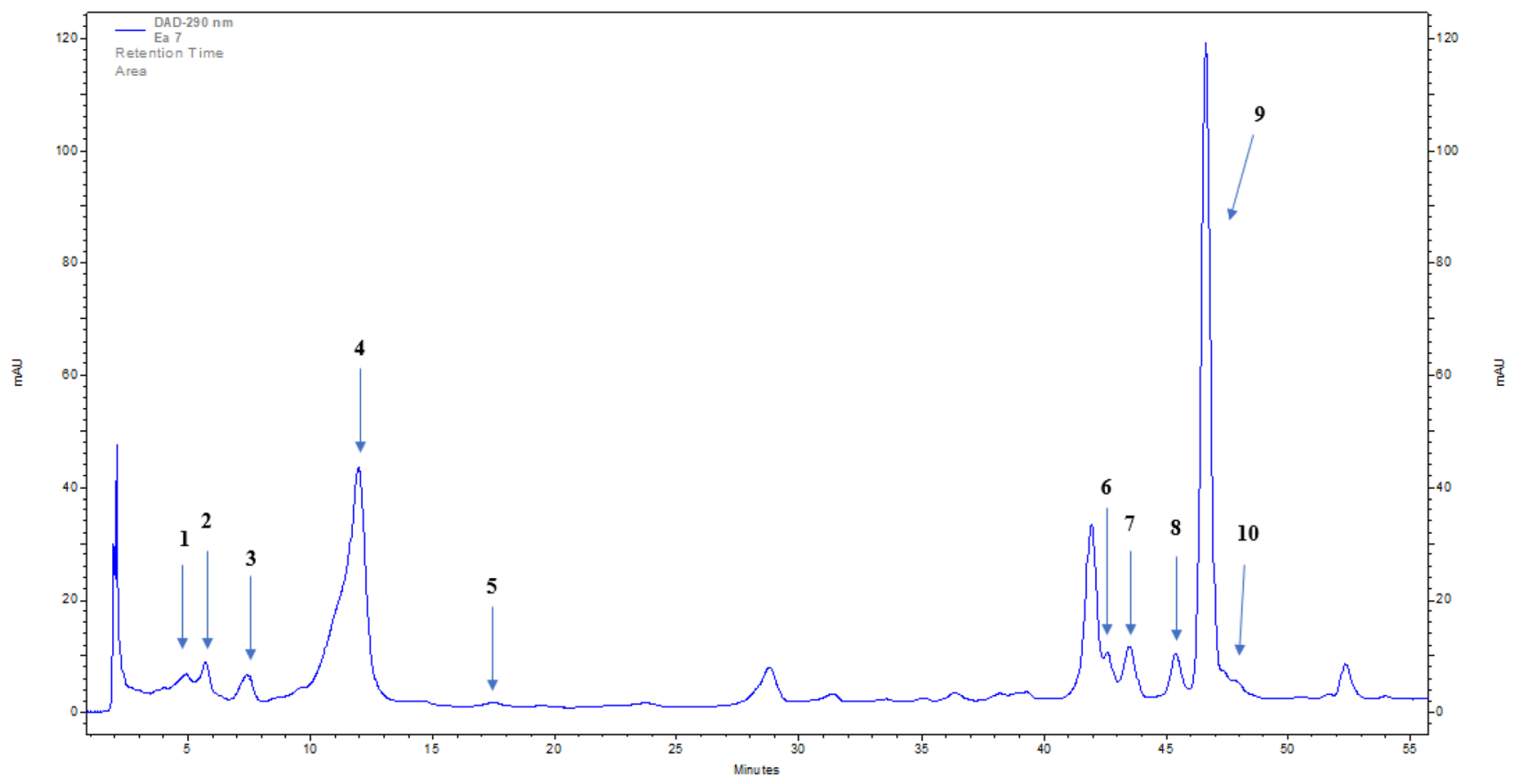

Extract in vitro shoots regenerated from callus: 1 - caftaric acid, 2 - neochlorogenic acid, 3 - 3,4-dihydroxyphenylacetic acid, 4 - chlorogenic acid, $\mathbf{5}$ - caffeic acid, $\mathbf{6}$ - isochlorogenic acid, 7 - isoquercetin, 8 - robinin, 9 - rosmarinic acid, $\mathbf{1 0}$ - quercitrin

Fig. 2 (continued)

Table 2 The contents $(\mathrm{mg} / 100 \mathrm{~g}$ DW $\pm \mathrm{SD})$ of estimated phenolic acids in the intact plant organs and in studied shoot culture systems of Eryngium alpinum

\begin{tabular}{|c|c|c|c|c|c|c|c|c|}
\hline \multirow[t]{2}{*}{ Phenolic acids } & \multicolumn{4}{|l|}{ Intact plant } & \multicolumn{4}{|l|}{ In vitro shoots } \\
\hline & Fruits & Roots & Stem leaves & Basal leaves & $\begin{array}{l}\text { From solid } \\
\text { media }\end{array}$ & $\begin{array}{l}\text { From liquid } \\
\text { media (agi- } \\
\text { tated) }\end{array}$ & $\begin{array}{l}\text { From liquid } \\
\text { media (station- } \\
\text { ary) }\end{array}$ & $\begin{array}{l}\text { Regenerated } \\
\text { from callus }\end{array}$ \\
\hline $\begin{array}{l}\text { 3,4-dihydroxy- } \\
\text { phenylacetic } \\
\text { acid }\end{array}$ & - & - & - & $13.28 \pm 0.24^{\mathrm{d}}$ & $44.70 \pm 3.07^{\mathrm{c}}$ & $100.25 \pm 4.33^{\mathrm{a}}$ & $52.15 \pm 3.43^{b}$ & $52.14 \pm 2.97^{\natural}$ \\
\hline $\begin{array}{l}\text { 4-dihydroxy- } \\
\text { benzoic }\end{array}$ & $0.76 \pm 0.05^{\mathrm{b}}$ & - & $2.13 \pm 0.16^{\mathrm{a}}$ & - & - & - & - & - \\
\hline $\begin{array}{l}\text { Chlorogenic } \\
\text { acid }\end{array}$ & - & $39.23 \pm 1.69^{\mathrm{d}}$ & - & $0.20 \pm 0.01^{\mathrm{e}}$ & $168.58 \pm 2.82^{\mathrm{a}}$ & $64.69 \pm 2.30^{c}$ & $94.26 \pm 1.64^{\mathrm{b}}$ & $59.77 \pm 4.20^{\circ}$ \\
\hline $\begin{array}{l}\text { Isochlorogenic } \\
\text { acid }\end{array}$ & - & $44.03 \pm 0.91^{\mathrm{a}}$ & - & $0.06 \pm 0.01^{\mathrm{e}}$ & $45.85 \pm 3.57^{\mathrm{a}}$ & $15.95 \pm 0.55^{\mathrm{c}}$ & $20.50 \pm 0.81^{b}$ & $13.33 \pm 0.82^{\circ}$ \\
\hline $\begin{array}{l}\text { Neochloro- } \\
\text { genic acid }\end{array}$ & - & $16.17 \pm 0.44^{\mathrm{c}}$ & - & - & $26.00 \pm 0.96^{\mathrm{a}}$ & $20.56 \pm 0.89^{b}$ & $26.49 \pm 0.96^{\mathrm{a}}$ & $19.58 \pm 0.59^{b}$ \\
\hline Caffeic acid & - & $0.08 \pm 0.01^{\mathrm{c}}$ & - & - & $3.49 \pm 0.19^{\mathrm{a}}$ & $3.46 \pm 0.23^{\mathrm{a}}$ & $3.22 \pm 0.14^{\mathrm{a}}$ & $2.45 \pm 0.08^{\mathrm{t}}$ \\
\hline Caftaric acid & - & $52.56 \pm 6.49^{\mathrm{a}}$ & - & - & $20.60 \pm 0.76^{\mathrm{b}}$ & $14.46 \pm 0.71^{\mathrm{c}}$ & $17.57 \pm 0.05^{\mathrm{b}}$ & $11.82 \pm 0.15$ \\
\hline $\begin{array}{l}\text { Rosmarinic } \\
\text { acid }\end{array}$ & - & $358.05 \pm 35.72^{\mathrm{a}}$ & - & $0.36 \pm 0.03^{\mathrm{f}}$ & $149.17 \pm 8.82^{\mathrm{c}}$ & $122.23 \pm 3.92^{\mathrm{d}}$ & $179.20 \pm 5.50^{\mathrm{b}}$ & $113.43 \pm 0.08$ \\
\hline Syringic acid & $0.14 \pm 0.04^{\mathrm{b}}$ & - & $1.02 \pm 0.04^{\mathrm{a}}$ & - & - & - & - & - \\
\hline Vanillic acid & $1.20 \pm 0.03^{\mathrm{b}}$ & - & $2.92 \pm 0.08^{\mathrm{a}}$ & - & - & - & - & - \\
\hline Sum & $2.10 \pm 0.12$ & $510.13 \pm 45.26$ & $6.07 \pm 0.28$ & $13.91 \pm 0.29$ & $458.38 \pm 20.19$ & $341.59 \pm 12.93$ & $393.40 \pm 12.53$ & $272.52 \pm 0.89$ \\
\hline
\end{tabular}

Mean values with a raw with the same letter are not significantly different at $\mathrm{P}=0.05$ (Duncan's multiple range test) 
Table 3 The contents $(\mathrm{mg} / 100 \mathrm{~g}$ DW $\pm \mathrm{SD})$ of estimated flavonoids in the intact plant organs and in studied shoot culture systems of Eryngium alpinum

\begin{tabular}{|c|c|c|c|c|c|c|c|c|}
\hline \multirow[t]{2}{*}{ Flavonoids } & \multicolumn{4}{|l|}{ Intact plant } & \multicolumn{4}{|l|}{ In vitro shoots } \\
\hline & Fruits & Roots & Stem leaves & Basal leaves & From solid media & $\begin{array}{l}\text { From liquid } \\
\text { media (agi- } \\
\text { tated) }\end{array}$ & $\begin{array}{l}\text { From liquid } \\
\text { media (station- } \\
\text { ary) }\end{array}$ & $\begin{array}{l}\text { Regenerated from } \\
\text { callus }\end{array}$ \\
\hline Isoquercetin & - & - & - & - & $25.77 \pm 1.38^{\mathrm{a}}$ & $21.50 \pm 0.86^{\mathrm{c}}$ & $29.26 \pm 1.50^{\mathrm{a}}$ & $20.08 \pm 1.50^{c}$ \\
\hline Quercitrin & $36.57 \pm 1.28^{\mathrm{b}}$ & - & $18.86 \pm 0.38^{\mathrm{e}}$ & $7.47 \pm 0.46^{\mathrm{f}}$ & $33.12 \pm 1.34^{\mathrm{c}}$ & $38.95 \pm 0.84^{\mathrm{b}}$ & $41.85 \pm 1.78^{\mathrm{a}}$ & $28.97 \pm 1.30^{\mathrm{d}}$ \\
\hline Trifolin & $9.13 \pm 0.16^{\mathrm{c}}$ & - & $26.26 \pm 0.93^{b}$ & $33.16 \pm 1.68^{\mathrm{a}}$ & - & - & - & - \\
\hline Kaempferol & $30.22 \pm 0.22^{\mathrm{b}}$ & - & $38.05 \pm 3.50^{\mathrm{a}}$ & - & - & - & - & - \\
\hline Robinin & - & - & - & - & $45.52 \pm 2.41^{\mathrm{d}}$ & $86.70 \pm 2.52^{\mathrm{a}}$ & $73.63 \pm 7.21^{\mathrm{b}}$ & $51.20 \pm 2.42^{\mathrm{c}}$ \\
\hline Sum & $75.91 \pm 1.66$ & $0.00 \pm 0.00$ & $83.17 \pm 4.81$ & $33.16 \pm 2.16$ & $146.98 \pm 5.13$ & $144.53 \pm 4.22$ & $104.27 \pm 10.49$ & $100.03 \pm 5.22$ \\
\hline
\end{tabular}

Mean values with a raw with the same letter are not significantly different at $\mathrm{P}=0.05$ (Duncan's Multiple Range Test)

acid, and vanillic acid were produced in stem leaves in the amounts respectively 2.8-, 7.2- and 2.4-times higher than in fruits. Roots possess the set of following phenolic acids: chlorogenic, isochlorogenic, neochlorogenic, caffeic, caftaric, and rosmarinic and the profile seemed to be similar to the composition of in vitro cultured shoots. Rosmarinic acid was quantitatively dominant phenolic acid, the best source of which was roots of the intact plant $(358.05 \mathrm{mg} / 100 \mathrm{~g}$ DW); and the amount of this acid was 1.99-higher than in shoots from the stationary liquid system $(179.20 \mathrm{mg} / 100 \mathrm{~g}$ DW), 2.4-higher than in shoots multiplied on the solid media (149.17 mg/100 g DW), 2.93-higher than in agitated shoots (122.23 mg/100 g DW), and 3.16-higher than in shoots regenerated from callus ( $113.43 \mathrm{mg} / 100 \mathrm{~g} \mathrm{DW})$. Moreover, chlorogenic acid at a higher concentration occurred in agitated shoots (100.14 mg/100 g DW) and it was 1.92-higher than in shoots from the liquid media (stationary system, $52.15 \mathrm{mg} / 100 \mathrm{~g} \mathrm{DW}$ ) and shoots regenerated from callus (52.14 mg/100 g DW), and also 2.24-higher than in shoots from the solid media. Caffeic acid was phenolic acid accumulated at the lowest concentration in shoots biomass from all the culture systems (from 2.45 to $3.49 \mathrm{mg} / 100 \mathrm{~g} \mathrm{DW}$ ). However, the best source of phenolic acids, with two dominant chlorogenic and rosmarinic acids, was shoots multiplied on the solidified media.

Rosmarinic acid is the main compound in many plant families, mostly in Lamiaceae and Boraginaceae, but also in Apiaceae family. The quantitative study of phenolic acids in roots from the species belonging to the Saniculoideae subfamily of Apiaceae family yielded rosmarinic acid in the ethanol-water (50\%) extracts of E. alpinum at the level of $27 \mathrm{mg} / \mathrm{g}$ DW, and the value was higher than in other Eryngium species-E. campestre $0.6 \mathrm{mg} / \mathrm{g}$ DW (45-fold higher) and E. planum $0.4 \mathrm{mg} / \mathrm{g}$ DW (67.5-fold higher) (Le Claire et al. 2005).

The qualitative and quantitative analyses of phenolic acids in biomass from in vitro cultures were also conducted for other Eryngium species (Kikowska et al. 2012, 2014, 2015,2016; Thiem et al. 2013). The organs of the intact plants and in vitro propagated plantlets as well as callus and cell suspension of $E$. planum were rich in rosmarinic, chlorogenic and caffeic acids. In shoots cultured on the solid MS medium, the content of rosmarinic acid was 3.5-times higher and of caffeic acid it was 24.33-times higher than in basal leaves of the intact plant (Kikowska et al. 2012). The analyses of E. planum shoots agitated in the liquid MS media confirmed the presence of rosmarinic, chlorogenic, and caffeic acids in all the examined materials, but the content significantly increased after elicitation (Kikowska et al. 2015). The content of two phenolic acids-rosmarinic acid and chlorogenic, was measured in shoots and roots of $E$. maritimum. In shoots cultured on the solid MS medium the content of rosmarinic acid was 4.96-times higher and of chlorogenic acid was 8.02-times higher than in basal leaves of the intact plant (Kikowska et al. 2014). Moreover, the content of rosmarinic acid, its hexoside and chlorogenic acid in organs of the intact plants and biomass from in vitro cultures was measured. Unfortunately, shoots cultures on the solid MS media accumulated those phenolic acids at a lower concentration than basal leaves of the intact plant (Kikowska et al. 2016).

The phytochemical studies on the presence and content of flavonoids showed a large variation between the tested materials (Table 3). The greatest differences occurred between the organs of the intact plant. Roots of the intact plant did not contain the studied flavonoids at all. In turn, the flavonoid profile of basal leaves was quite poor, as only quercetin $(7.47 \mathrm{mg} / 100 \mathrm{~g} \mathrm{DW})$ and rutoside $(33.16 \mathrm{mg} / 100 \mathrm{~g}$ DW) were detected. Robinin was present only in shoots cultivated in in vitro cultures; its highest content was found in shoots from the liquid media $(86.70 \mathrm{mg} / 100 \mathrm{~g} \mathrm{DW})$ and was about 1.2-times higher than in shoots from the liquid medium maintained on paper bridges, 1.7-times higher than in shoots regenerated from callus, and 1.9-times higher 
than in shoots propagated on the solid media. Shoots from in vitro cultures were not able to accumulate trifolin and kaempferol in contrast to stem leaves of the intact plants $(9.13 \mathrm{mg} / 100 \mathrm{~g} \mathrm{DW}$ and $30.22 \mathrm{mg} / 100 \mathrm{~g} \mathrm{DW}$, respectively) and roots $(26.26 \mathrm{mg} / 100 \mathrm{~g}$ DW and $38.05 \mathrm{mg} / 100 \mathrm{~g} \mathrm{DW})$. The content of isoquercetin was similar in shoots cultured in different in vitro systems (from $20.08 \mathrm{mg} / 100 \mathrm{~g}$ DW to $29.26 \mathrm{mg} / 100 \mathrm{~g} \mathrm{DW}$ ), while there was a lack of it in stem and basal leaves of the intact plant. Summarizing, the richest raw materials in terms of the amount of flavonoids turned out to be shoots grown in vitro, in the following order: shoots from the agitated liquid medium, shoots from the liquid medium cultured on paper bridges, shoots multiplied on the solid media, and shoots regenerated from callus (Table 3 ). According to literature data, the content of flavonoids in other Eryngium species has not been measured in in vitro biomass never before.

Our studies have demonstrated the importance of the type of culture system on the selected phenolic compounds accumulation in the studied Eryngium alpinum L. biomass.

\section{Conclusion}

In vitro shoot cultures of Eryngium alpinum-protected species may offer a promising source of phenolics without harvesting the plant material from the natural environment.

\begin{abstract}
Author contributions MK is the author of conception, who designed the study, initiated and maintained in vitro cultures, and wrote the manuscript. MK collected the plant material. AS, MK-S performed and elaborated the phytochemical analyses. BT, AS, and HE corrected and improved the manuscript. All the authors contributed to data interpretation, critical revision of the manuscript, and its final approval.
\end{abstract}

\section{Compliance with ethical standards}

Conflict of interest The authors declare that they have no conflict of interest.

Open Access This article is licensed under a Creative Commons Attribution 4.0 International License, which permits use, sharing, adaptation, distribution and reproduction in any medium or format, as long as you give appropriate credit to the original author(s) and the source, provide a link to the Creative Commons licence, and indicate if changes were made. The images or other third party material in this article are included in the article's Creative Commons licence, unless indicated otherwise in a credit line to the material. If material is not included in the article's Creative Commons licence and your intended use is not permitted by statutory regulation or exceeds the permitted use, you will need to obtain permission directly from the copyright holder. To view a copy of this licence, visit http://creativecommons.org/licenses/by/4.0/.

\section{References}

Arockiasamy S, Ignacimuthu S (1998) Plant regeneration from mature leaves and roots of Eryngium foetidum L., a food flavouring agent. Curr Sci 75:664-666

Arockiasamy S, Prakash S, Ignacimuthu S (2002) Direct organogenesis from mature leaf and petiole explants of Eryngium foetidum L. Biol Plant 45:129-132. https://doi.org/10.1023/A:101517733

Ayuso M, Garcia-Perez P, Ramil-Rego P, Gallego PP, Barreal ME (2019) In vitro culture of the endangered plant Eryngium viviparum as dual strategy for ex situ conservation and source of bioactive compounds. Plant Cell Tissue Organ Cult. https://doi. org/10.1007/s11240-019-01638-y

Chandrika R, Vyshali P, Saraswathi KJT, Kaliwal BB (2011) Rapid multiplication of mature flowering plant of Eryngium foetidum $\mathrm{L}$. by in vitro technique. IJBA 3:114-117. https://doi. org/10.9735/0975-2975-2943.3.4.114-117

Cheynier V (2012) Phenolic compounds: from plants to foods. Phytochem Rev 2-3:153-177. https://doi.org/10.1007/s1110 1-012-9242-8

Crowden RK, Harborne JB, Heywood VH (1969) Chemosystematics of the Umbelliferae-a general survey. Phytochemistry 8:1963-1984. https://doi.org/10.1016/S0031-9422(00)88084-x

Dunkic V, Vuko E, Bezic N, Kremer D, Ruscic M (2013) Composition and antiviral activity of the essential oils of Eryngium alpinum and E. amethystinum. Chem Biodivers 10:1894-1902. https://doi.org/10.1002/cbdv.201300061

Ellnain-Wojtaszek M, Zgorka G (1999) High-performance liquid chromatography and thin-layer chromatography of phenolic acids from Ginkgo biloba L. leaves collected within vegetative period. J Liq Chromatogr Relat Technol 22:1457-1471. https:// doi.org/10.1081/JLC-100101744

Espinosa-Leal CA, Puente-Rarza CA, Garcia-Lara S (2018) In vitro plant tissue culture: means for production of biological active compounds. Planta 248:1-18. https://doi.org/10.1007/s0042 5-018-2910-1

Garg SK, Shukla A, Choudhurry S (2019) Polyphenols and flavonoids. In: Gupta R, Srivastava A, Lall R (eds) Nutraceuticals in veterinary medicine. Springer, Cham. https://doi. org/10.1007/978-3-030-04624-8_13

Gaudeul M, Till-Bottraud I (2004) Reproductive ecology of the endangered Alpine species Eryngium alpinum L. (Apiaceae): phenology, gene dispersal and reproductive success. Ann Bot 93:711-721. https://doi.org/10.1093/aob/mch098

Gillot P, Garraud L (1995) Eryngium alpinum (L.) In: Livre Rouge de la Flore Menacée, p. 185. Museum National d'Histoire Naturelle, Conservatoire Botanique National de Porquerolles, Ministère de l'Environnement, Paris, France

Grzegorczyk-Karolak I, Rytczak P, Bielecki S, Wysokińska H (2017) The influence of liquid systems for shoot multiplication, secondary metabolite production and plant regeneration of Scutellaria alpina. Plant Cell Tissue Organ Cult 128(2):479-486. https:// doi.org/10.1007/s11240-016-1126-y

Gygax A, Bernhardt KG, Jogan N, Montagnani C, Gigot G (2013) Eryngium alpinum. In: The IUCN Red List of Threatened species. Version 2014.3

Ignacimuthu S, Arockiasamy S, Antonysamy M, Ravichandran P (1999) Plant regeneration through somatic embryogenesis from mature leaves of Eryngium foetidum L. a condiment. Plant Cell Tissue Organ Cult 56:131-137. https://doi.org/10.1023/A:10062 28310864

Kikowska M, Thiem B (2020) In vitro systems of selected Eryngium species (E. planum, E. campestre, E. maritimum, and E. alpinum) for studying production of desired secondary metabolites (phenolic acids, flavonoids, triterpenoid saponins, and essential 
oil). Springer, Cham. https://doi.org/10.1007/978-3-030-11253 $-0 \_29-1$

Kikowska M, Budzianowski J, Krawczyk A, Thiem M (2012) Accumulation of rosmarinic, chlorogenic and caffeic acids in in vitro cultures of Eryngium planum L. Acta Physiol Plant 34:2425-2433. https://doi.org/10.1007/s11738-012-1011-1

Kikowska M, Thiem B, Sliwinska E, Rewers M, Kowalczyk M, Stochmal A, Oleszek W (2014) The effect of nutritional factors and plant growth regulators on micropropagation and production of phenolic acids and saponins from plantlets and adventitious root cultures of Eryngium maritimum L. J Plant Growth Regul 33:809819. https://doi.org/10.1007/s00344-014-9428-y

Kikowska M, Kedziora J, Krawczyk A, Thiem B (2015) Methyl jasmonate, yeast extract and sucrose stimulate phenolic acids accumulation in Eryngium planum L. shoot cultures. Acta Biochim Pol 62:197-200. https://doi.org/10.18388/abp.2014_880

Kikowska M, Thiem B, Sliwinska E, Rewers M, Kowalczyk M, Stochmal A, Długaszewska J (2016) Micropropagation of Eryngium campestre $\mathrm{L}$. via shoot culture provides valuable uniform plant material with enhanced content of phenolic acids and antimicrobial activity. Acta Biol Cracov Bot 58:43-56. https://doi. org/10.1515/abcsb-2016-0009

Kikowska M, Thiem B, Szopa A, Klimek-Szczykutowicz M, Rewers M, Sliwinska E, Ekiert H (2019) Comparative analysis of phenolic acids and flavonoids in shoot cultures of Eryngium alpinum L.: an endangered and protected species with medicinal value. Plant Cell Tissue Organ Cult 139:167. https://doi.org/10.1007/s1124 0-019-01674-8

Le Claire E, Schwaiger S, Banaigs B, Stuppner H, Gafner F (2005) Distribution of a new rosmarinic acid derivative in Eryngium alpinum L. and other Apiaceae. J Agric Food Chem 53:4367-4372. https ://doi.org/10.1021/ji050024v

Malik S, Sharma M, Ahuja PS (2016) An efficient and economic method for in vitro propagation of Arnebia euchroma using liquid culture system. Am J Biotechnol Med Res 1(1):19-25. https://doi. org/10.5455/ajbmr.20160501100040

Martin KP (2004) Efficacy of different growth regulators at different stages of somatic embryogenesis in Eryngium foetidum L.- - a rare medicinal plant. In Vitro Cell Dev Biol Plant 40:459-463. https:// doi.org/10.1079/IVP2004543

Matkowski A (2008) Plant in vitro culture for the production of antioxidants. Biotechnol Adv 26:548-560. https://doi.org/10.1016/j. biotechadv.2008.07.001

Murashige T, Skoog F (1962) A revised medium for rapid growth and bioassays with tobacco cultures. Physiol Plant 15:473-497

Njenga J (1995) Production of Eryngium. N.C. Flower Growers' Bull 40(4):9-11
Savio LEB, Astarita LV, Santarem ER (2011) Secondary metabolism in micropropagated Hypericum perforatum L. grown in non-areated liqiud medium. Plant Cell Tissue Organ Cult 108(3):465-472. https://doi.org/10.1007/s11240-011-0058-9

Smetanska I (2018) Sustainable production of polyphenols and antioxidants by plant in vitro cultures. In: Pavlov A, Bley T (eds) Bioprocessing of plant in vitro systems. Reference series in phytochemistry. Springer, Cham, pp 225-269. https://doi. org/10.1007/978-3-319-54600-1_2

Szopa A, Kokotkiewicz A, Marzec-Wróblewska U, Buciński A, Luczkiewicz M, Ekiert H (2016) Accumulation of dibenzocyclooctadiene ligans in agar cultures and in stationary and agitated liquid cultures of Schisandra chinensis (Turcz.) Baill. Appl Microbiol Biotechnol 100(9):3965-3977. https://doi.org/10.1007/s0025 3-015-7230-9

Szopa A, Kokotkiewicz A, Bednarz M, Luczkiewicz M, Ekiert H (2017a) Studies on the accumulation of phenolic acids and flavonoids in different in vitro culture systems of Schisandra chinensis (Turcz.) Baill. using a DAD-HPLC method. Phytochem Lett 20:462-469. https://doi.org/10.1016/j.phytol.2016.10.016

Szopa A, Kokotkiewicz A, Kubica P, Banaszczak P, WojnatowskaKrośniak A, Krośniak M, Marzec-Wróblewska U, Badura A, Zagrodzki P, Buciński A, Luczkiewicz M, Ekiert H (2017b) Comparative analysis of different groups of phenolic compounds in fruit and leaf extracts of Aronia sp.: A. melanocarpa, A. arbutifolia and A. xprunifolia and their antioxidant activities. Eur Food Res Techno. https://doi.org/10.1007/s00217-017-2872-8

Tascan A, Adelberg J, Tascan M, Rimando A, Joshee N, Yadav AK (2010) Hyperhydricity and flavonoid content of Scutellaria species in vitro on polyester-supported liquid culture systems. Hort Science 45(11):1723-1728. https://doi.org/10.21273/HORTS CI.45.11.1723

Thiem B, Kikowska M, Krawczyk A, Więckowska B, Sliwinska E (2013) Phenolic acid and DNA contents of micropropagated Eryngium planum L. Plant Cell Tissue Organ Cult 114:197-206. https ://doi.org/10.1007/s11240-013-0315-1

Wang P, Su Z, Yuan W, Deng G, Li S (2012) Phytochemical constituents and pharmacological activities of Eryngium L. (Apiaceae). Pharm Crops 3:99-120. https://doi.org/10.2174/2210290601 203010099

Publisher's Note Springer Nature remains neutral with regard to jurisdictional claims in published maps and institutional affiliations. 